\section{Error in the dosage of Methotrexate in the EULAR/ERA-EDTA recommendations for the management of ANCA-associated vasculitis}

The EULAR/ERA-EDTA recommendations for the management of ANCA-associated vasculitis $(\mathrm{AAV})^{1}$ are a pillar in the treatment of patients with these diseases worldwide. Hence, it is of the utmost importance that information, especially dosing be correct and therefore reliable. More than in some other rheumatic diseases AAV oftentimes requires treatment from a multidisciplinary team. For physicians from other specialties dosing might not be as familiar as it is for rheumatologists.

Statement 7 of the recommendations suggests a dose of Methotrexate with $20-25 \mathrm{mg} / \mathrm{kg} /$ week for remission maintenance of AAV. This recommended dose would almost certainly be toxic and lead to complications or even death. Patients die every year from wrong dosing of Methotrexate.

I suggest that in the future, before publishing recommendations for the management of rheumatic diseases an additional layer of security be implemented by separate review of every suggested dose of every medication in the publication for mistakes or typos because every mistake, howsoever small, can have far reaching consequences for our patients.

\section{Dennis Scheicht}

Correspondence to Dr Dennis Scheicht, Clinic of Rheumatology, Krankenhaus Porz am Rhein gGmbH, Cologne 51149, Germany; dscheicht@gmail.com

Funding The authors have not declared a specific grant for this research from any funding agency in the public, commercial or not-for-profit sectors.

Competing interests None declared.

Patient consent for publication Not required.

Provenance and peer review Not commissioned; internally peer reviewed.

(c) Author(s) (or their employer(s)) 2020. No commercial re-use. See rights and permissions. Published by BMJ.

\section{Check for updates}

To cite Scheicht D. Ann Rheum Dis Epub ahead of print: [please include Day Month Yearl. doi:10.1136/annrheumdis-2020-217041

Received 24 January 2020

Accepted 25 January 2020

Ann Rheum Dis 2020;0:1. doi:10.1136/annrheumdis-2020-217041

ORCID iD

Dennis Scheicht http://orcid.org/0000-0002-0600-0998

\section{REFERENCE}

1 Yates M, Watts RA, Bajema IM, et al. EULAR/ERA-EDTA recommendations for the management of ANCA-associated vasculitis. Ann Rheum Dis 2016;75:1583-94. 